\title{
The Neglected Politics Behind EU Annulment Litigation
}

In September 2016, Ireland and Apple announced that they were taking the European Commission to the Court of Justice of the European Union (CJEU). ${ }^{1}$ They questioned the legality of a Commission decision that demanded that Ireland reclaim billions of euros from Apple, the multinational technology company. ${ }^{2}$ The Commission regarded the Irish tax arrangement with Apple as violating European Union (EU) state aid law. According to the Commission, Apple enjoyed an undue tax advantage that it had to pay back. The subsequent Commission decision was thus bound to have ample consequences for both Ireland and Apple. Yet although the decision would flush thirteen billion euros into the Irish public budget, the Irish government was dominated by the fear of losing jobs if business-friendly tax deals with Apple and other companies were no longer an option. In addition, Apple's profits would take a considerable cut, putting pressure on its management and sending shivers through its shareholders. On the other side of this conflict, the Commission strongly emphasized its obligation to prevent collusive tax pacts that might spiral into self-defeating fiscal competition among member states.

Despite the political drama surrounding the case, little attention was paid to the supranational legal instrument - the annulment procedure-used as a last resort by Apple to prevail in this conflict with the Commission. According to EU law, the annulment procedure constitutes the only legal route to contest a supranational act or particular Commission decision about the national implementation of European

(C) The Author(s) 2020

C. Adam et al., Taking the EU to Court, Palgrave Studies in European Union Politics, https://doi.org/10.1007/978-3-030-21629-0_1 
policies (Article $263 \mathrm{TFEU}) .{ }^{3}$ By launching an annulment action against the EU executive, Apple was thus asking to review the lawfulness of the supranational decision, hoping that the Court would find it to be in violation of EU law and therefore annul it. Ireland actively and officially supported Apple's case in court by intervening with legal arguments in its favour, while the Commission found a legal supporter in the European Free Trade Association Surveillance Authority. Even the United States government tried to take on an active role by supporting Apple and Ireland in court. The Court rejected the United States' application, however, and denied it formal access to these court proceedings. ${ }^{4}$

The extraordinary attention the Apple case received most likely stemmed from the involvement of a world-famous company and the enormous amount of money that was disclaimed by politicians. However, the case also carries substantial political implications for the emerging EU multilevel order. "If the Commission prevails in court, the decision will reset the balance of power on tax policy in Europe. While governments will still be able to set their own tax rates, the Commission will have established itself as a watchful referee of how national rules are implemented. Success on appeal for Apple and Ireland might relieve some of that pressure and give national governments more leeway', analysed the Financial Times (Houlder et al. 2016). Whether the Court will rule in favour of the Commission or in favour of Ireland and Apple is still an open question at the time of writing. At any rate, this instance highlights that annulment actions have become an important legal battleground for EU policy making and system development.

If one single annulment decision can crucially affect the future balance of power in tax policy in the EU, then what about the other several dozens of annulment cases that are decided each year? Are they equally important? The frank answer to this question is that we do not know. Considering the potential impact of EU annulment actions, it is striking that they evaded the focus of students of the European multilevel system for so long. In view of this gap, the aim of this book is to explore EU annulment actions and their political relevance for EU multilevel governance.

As we will argue in this book, annulment actions are part of the struggle over policy decisions and system development in the emerging multilevel political order of the EU. They often represent what seems like a measure of last resort with which national governments, regional governments, interest groups, companies, and even other EU institutions 
try to fight off interferences of (other) EU institutions. Moreover, we will argue that the initiation of an action for annulment is by no means an automatic and legalistic reaction to EU institutions breaching their mandates and overstepping their competences. Even blatant breaches of EU law will only attract annulment litigation when this is in the political and/or financial interest of stakeholders. At the same time, even where the pleas for actions for annulment seem highly dubious, with very slim chances for success, initiating an action for annulment can be in the political and/or financial interest of some actors. Simply put, annulment actions are a legal instrument that is typically used for political reasons and often has the power to yield significant political consequences as a result of its impact on policy content, political procedures, and the EU's constitutional order. This calls for political science research to complement legal scholarship on annulment actions. The common multilevel nature of annulment conflicts underlines yet again the importance of understanding the EU as a multilevel system. If we fail to understand the role of these conflicts in which public actors from multiple levels of government, as well as interest groups, companies, and EU institutions, directly accuse (other) EU institutions of violating EU law, we arguably fail to understand a substantial part of this multilevel system. This book intends to improve our understanding of these conflicts by focussing first on the motivation of actors to litigate, second on the configurations of actors involved, and third on the outcome of the rulings and their effect on policy substance and competence distribution in the EU multilevel system.

Unsurprisingly, annulments as devices of EU law have so far been the concern primarily of legal scholarship. As we argue in the following chapters, to understand the role of annulment actions within the EU multilevel system, it is essential to consider their political dimension as well (Bauer and Hartlapp 2010; Adam et al. 2015; Adam 2016; Hartlapp 2018; Mathieu et al. 2018). Without investigating their political nature, without looking at the underlying motivations of actors, and without gauging the potential impact of such litigation, our understanding of annulments will remain partial and inadequate. As the Apple case suggests, annulments may be politically and economically highly relevantin our view, reflecting an increasingly important feature of emerging multilevel conflict over supranational decision making and implementation. This makes annulment litigation a fascinating subject for political 
scientists, especially for those interested in multilevel politics and EU policy making.

Against this background, this book provides a political perspective of EU annulments, combining qualitative and quantitative empirical insights and theoretical analysis. Essentially, our argument centres around two concepts: actors' motivations and actor configurations.

First, we argue a legalistic understanding of actions for annulment that expects annulment actions to emerge only when the suspicion that an EU institution has breached its mandate and overstepped its competences falls short of the empirical reality. Instead, annulments are regularly initiated in the attempt to influence policies and competence allocation in the EU by a variety of actors with different motivations. The literature on private litigants typically presumes that companies are motivated by financial gains, while non-governmental organizations go to court to push forward ideological and policy preferences. This presumption seems overly simplistic for the context of litigating public actors that are motivated by keeping or expanding institutional competences in addition to seeking policies and material gains. Here, motivations cannot simply be presumed, but instead must be uncovered by research. To do so, it is essential to identify and analyse the conflict that underlies and precedes the decision to litigate. We distinguish four ideal types of motivations for litigation: material gains, institutional competences, ideology and policy preferences, and political trust. We derive these motivations by analysing actors' problems, demands, and preferences within the multilevel policy process that gives rise to annulment litigation. This allows us to describe actors' motivations for going to court (why they consider litigating), as well as the conditions that influence when actors go to court, such as the legal opportunity structures and the merits of a case. On this basis, we try to move beyond simple risk-benefit analysis to explain litigation behaviour. After all, for some motivations, it is very difficult to quantify the expected benefits of litigation. Moreover, different actors feel very differently about legal uncertainty and even the slim chances of legal success. In fact, we have to take into account that for public litigants, even losing cases can be beneficial for them (Adam et al. 2015).

Second, next to motivations, our argument puts actor configurations centre stage. Sometimes, annulment conflicts are fought between just one applicant and one defendant EU institution-a member state litigating against the Council of the European Union, or a private company 
litigating against the Commission, for example. Quite frequently, however, the litigant configuration in court is much more complex than that, including actors from multiple levels of government, and private and public actors on both sides of the conflict. While we are far from able to predict the emergence of such complex constellations in individual cases, we present evidence that suggests that the emergence of complex multilevel configurations is more likely during times of institutional turbulence at the EU level, for example, in times of treaty change or-at a smaller scale-in response to disruptive policy changes. In such situations of institutional turbulence, established legal paths and orders become unsettled. Moreover, the incentives to go to court increase in times of turbulence. This is because disrupted legal regimes create more legal grey areas for the Court to colour in with its rulings. After all, the Court has not had the chance to interpret and specify new or altered treaty articles or directives. Provoking influential precedent rulings is more likely to occur soon after turbulence and can be very valuable to litigants for a number of reasons. Particularly when there is a chance to have the Court colour in rather large legal grey areas due to turbulence, litigation can be chosen for various motivations, be it for material gain, to gain institutional competences, of to attain ideological goals. For the same reason that institutional turbulence increases the stakes for potential litigants on either side of conflicts, it also makes court rulings less predictable. Since there is no long history of court rulings interpreting new or modified treaty articles or directives, the Court's take on these new and revised legal acts remains unknown until such a history of rulings is established. Existing case law cannot easily be used to predict court behaviour without considerable uncertainty. Therefore, institutional turbulence creates legal uncertainty and incentives to try to provoke precedent rulings. This not only incentivizes more actors to take an active role in annulment litigation resulting in a greater number of complex actor configurations. This also creates a situation in which the success rate for these complex actor configurations is much closer to $50 \%$ than for simple actor configurations. Simply put, when court rulings are easy to foresee-as would be the case with a long history of relevant court rulings on an issuefewer actors will be drawn to take an active part in annulment proceedings than when court rulings are rather difficult to foresee; that is, where chances of success are close to 50:50. Consequently, we argue that we should not be too quick to attribute the significantly different success rates for simple versus complex actor configurations to a causal impact of 
the actor configuration on the judges at Luxembourg. Instead, it rather indicates that the legal cases that give rise to simple actor configurations are significantly different from the cases that trigger complex actor configurations in court.

Annulment actions thus serve one rather clearly defined legal purpose: to keep supranational institutions in (legal) check. And yet we hope to convincingly show that at the same time, they also serve various political purposes. These political purposes reach all the way from gaining political trust from domestic constituents, to reaching ideological goals, to expanding institutional competences, all the way to hoping for material gains. While (Article 258 TFEU) infringement proceedings have helped the Commission to push the Europeanization of national policies ahead (e.g. Tallberg 2002), and preliminary reference proceedings (Article 267 TFEU) have helped to boost the European integration process (e.g. Burley and Mattli 1993), it is more difficult to pinpoint the role of annulment actions. Annulment proceedings have helped to restrict the power and influence of EU institutions in some areas but also helped to expand their competences in other areas. Most importantly, however, annulment actions have given various types of actors and the Court the chance to continuously adjust and fill in the (legal) gaps within the developing EU polity. Thereby, they have influenced not only policy content but also the competences of EU institutions and their relationship to member states, regional governments, interest groups, companies, and citizens.

\section{Policy and Institutional Relevance of AnNulments}

Annulment actions are thus one important channel for judicial review in the EU. Judicial review is a process under which the actions of public actors are subject to the review of the judiciary. The competent court may invalidate an executive or legislative decision for being unlawful or unconstitutional. Judicial review is a key element of the checks and balances in the separation of powers. It allows the judiciary to put a halt on executive or legislative decisions that go beyond their competences.

Research in the area of law and politics provides abundant examples of how judicial review can lead to far-reaching policy and institutional changes. Many social movements have used judicial review to 
push forward their agenda, achieving impressive results in some cases thanks to the United States Supreme Court's relative judicial openness in certain policy issues, such as the defence of minorities (Meyer and Boutcher 2007). We also know from the literature on federalism that judicial review can lead constitutional courts to play a prominent role in the redefinition of central-regional competence distribution (Laufer and Münch 1998; Swenden 2006, 79-89).

In the EU, judicial review through annulment actions can have far-reaching policy and institutional impacts. The policy impact of annulments is particularly visible in the context of state aid policy. EU state aid policy prohibits governmental subsidies to economic actors when they distort competition on the internal market (there are nevertheless exceptions to this rule under specific circumstances). The crucial and decisive task of assessing whether a subsidy is compatible with the internal market belongs to the Commission. How the Commission interprets the compatibility with the internal market is often subject to examination that also includes the Court and the case law it has produced in the past. Annulment actions, raised against the Commission's state aid decisions, have therefore often contributed to clarifying the conditions under which the Commission may and may not prohibit national aids. Thereby, these annulment rulings have not only affected the substance of state aid policy but also influenced the balance of power between the Commission and the member states.

One example for the effect of annulment litigation on the balance of power between the Commission and the member states is case T-21/06, initiated by Germany in 2006. In the course of its annulment ruling, the Court legitimized the Commission's newly established practice of tying acceptable state aid provision to the occurrence of market failure. In the specific case, Germany had subsidized two private broadcasting companies (ProSiebenSat.1 and RTL Group) in order to successfully rollout digital TV receivable through antenna in the Berlin-Brandenburg area. The Commission declared these aids illegal and justified this decision with reference to the newly established concept of market failure: the subsidy is authorized only if it was an effective and proportionate instrument to address a market failure. This connection between market failure and the legality of national state aid policy was not included in the treaties. It was only established in the Commission's State Aid Action Plan (SAAP) adopted in 2005 (European Commission 2005, 4). Due to the 
indeterminate legal nature of this concept, its introduction would ensure a maximal level of discretion for the Commission. This is why in its advisory statement during the consultation period of the SAAP in 2005, the German government explicitly complained that the concept of market failure as introduced by the Commission was not an appropriate foundation for assessing national state aid (Federal Republic of Germany 2005, 3). The Commission's use of the market failure concept in this particular case provided Germany with the opportunity to involve the CJEU to either revoke or specify the role of market failure in the context of state aid control. Germany, however, lost this case and helped to clarify that the Court would accept market failure as a criterion for evaluating the legality of state aid measures. Due to the substantial room for interpretation this concept gives to the Commission, this annulment conflict has arguably tilted the balance of power over state aid policy further towards the Commission.

Annulments can also have significant effects on national politics, as the following case dealing with suckler-cow premiums (C-344/01) indicates. This case, related to EU agricultural funds, had a profound impact on the relationship between central and regional levels of government in Germany. In Germany, as is often the case in federal or regionalized countries, the practical management of EU agricultural funds is delegated to lower levels of government-in the German case, to the Länder (German states). In case a state fails to comply with EU requirements in terms of supervision and control of how the funds are spent, the Commission refuses to refinance the corresponding amount of money to the member state. In Germany, this sanction primarily hurt the federal budget from which the money had been advanced, because no compensation rule that would transfer the financial burden of the sanction to the non-compliant state's budget existed. The German federal government had been eager to change this situation. But because of the states' collective opposition to such a change, the status quo remained. Yet this situation changed in response to the so-called suckler-cow premiums case, which took place during lengthy negotiations between the federal government and the states about important reforms of German federalism. This was yet another instance in which the Commission found that several German states had failed to follow EU rules when paying out premiums to farmers for suckler cows and imposed financial sanctions. Again, the federal government would be stuck with these sanctions without a mechanism to divert them to the noncomplying states. In this situation, annulment litigation must have seemed like an obvious course 
of action. After all, in the event of success in court, the financial sanction would just disappear. Even more importantly, in the opposite outcome of legal defeat, the court ruling would put further pressure on the states to compromise about the redistribution of financial responsibilities in case of financial sanctions related to the spending of EU money. When the Court ruled against Germany, the federal government was able to instrumentalize the ruling and managed to successfully negotiate an amendment to the German constitution (Article 104a), specifying that where the Länder are the regional entities implementing Germany's supranational responsibilities, $15 \%$ of resulting financial corrections would be covered by the federal budget, while $85 \%$ would from then on be covered by the Länder budgets (Adam et al. 2015). In other words, the German federal government lost this annulment case, rather successfully leaving a mark in the German constitution.

Moreover, annulment actions can also have a profound impact on the distribution of competences between EU institutions. The ERTA case $(\mathrm{C}-22 / 70)$ is proof of this. Here, the Commission sued the Council for having prevented the Commission from negotiating an international agreement in the field of transport. Traditionally, member states would negotiate international trade agreements only in those areas of external policy where the EU is not competent. In that case, the Council had authorized member states to negotiate and conclude an international transport agreement that included social rules for the protection of drivers. While the Council claimed that transport was a national competence (currently, Article 95 TFEU), the Commission felt that the Council had overstepped its competences and launched an annulment to shift the legal base so negotiation powers would fall on the Commission (today Article 207 TFEU). The Court additionally granted that the existence of an acquis communautaire harmonizing social provisions in transport (Regulation 543/69) necessarily vested any international agreement in community powers-consequently excluding concurring powers of member states in trade negotiations. This legal interpretation implied that the Commission could expand its external policy competences to areas where the EU holds internal competences. This became known as the principle of implied powers and was further developed and eventually codified in the Nice Treaty (Cremona 2011), leaving a lasting effect in primary law.

Such far-reaching institutional adjustments triggered by annulment actions may also take place below the level of formal treaty changes, for 
example, through the modification of administrative practices. After having lost numerous annulment rulings on the application of the post-Lisbon comitology structure, the Commission secretariat general issued an internal guideline to its policy directorate generals to be particularly vigilant during law making. Annulment cases had the effect of limiting the Commission's influence on the delegation and implementation of acts. To compensate its loss of influence at the level of comitology, the Commission changed its approach, favouring the inclusion of detailed policy preferences in the drafting of legislative acts. Because of annulment actions, the Commission thus developed a new procedural strategy consisting of fixing things at an earlier stage rather than leaving room for policy making to the Council and the European Parliament (EP) via implementing and delegating acts (COM_1). ${ }^{5}$

In all these examples, annulment actions emerged from conflicts among a few actors and appear, at first sight, to be of minor importance because they seemed to deal merely with sector-specific issues and individual implementation decisions. Nevertheless, they brought about long-lasting and far-reaching formal and informal policy and institutional adaptations to the EU multilevel system, at times shifting the balance of policy-making powers. In the digital TV case, for example, a conflict between the Commission on one hand and Germany and two broadcasting companies on the other resulted in a wide extension of the Commission's room for interpreting EU state aid law, thanks to the Court's acknowledgement of the concept of market failure. In the suckler-cow premiums case, a conflict between Germany and the Commission on an apparently highly technical issue allowed the federal state to significantly reshape its financial relationship with German states in agriculture policy with respect to paying for supranational fines. An annulment case also coined the far-reaching and now famous doctrine of implied powers, allowing the Commission to significantly expand its competences in external affairs to the detriment of the Council and of the member states. Finally, annulment actions also led the Commission to revise its procedural strategy with a view to maximizing its influence on EU policies, leading to the expansion of detailed legislation to the detriment of delegation and implementing comitology acts. There should thus be no doubt that annulment actions play a crucial role in the EU's multilevel system. Ignoring the political role of annulment conflicts carries the risk of missing important aspects of how conflicts shape policy contents and policy process in the EU's multilevel system. 


\section{Annulment Over Time and Across Policy Areas: EMPIRICAL EVIDENCE}

Annulments are relevant not only in qualitative terms; they also emerge in quite significant numbers. Due to expanding competences of the European Commission and other EU institutions, such as the EP, the need to keep these supranational institutions in check via judicial review has increased over time, and so has the number of annulment cases directed against legal acts adopted by these institutions. Since the 1960s, there has been a clear increase in the number of annulment actions filed against EU institutions (see Fig. 1.1). At the same time, this increase is characterized by fluctuations. Chapter 5 offers a much closer look at the peaks and lows in the number of annulment actions over time.

But annulment actions have not only increased in number. They have also captured more and more policy sectors, slowly spreading across the whole spectrum of policy sectors in which EU institutions have become

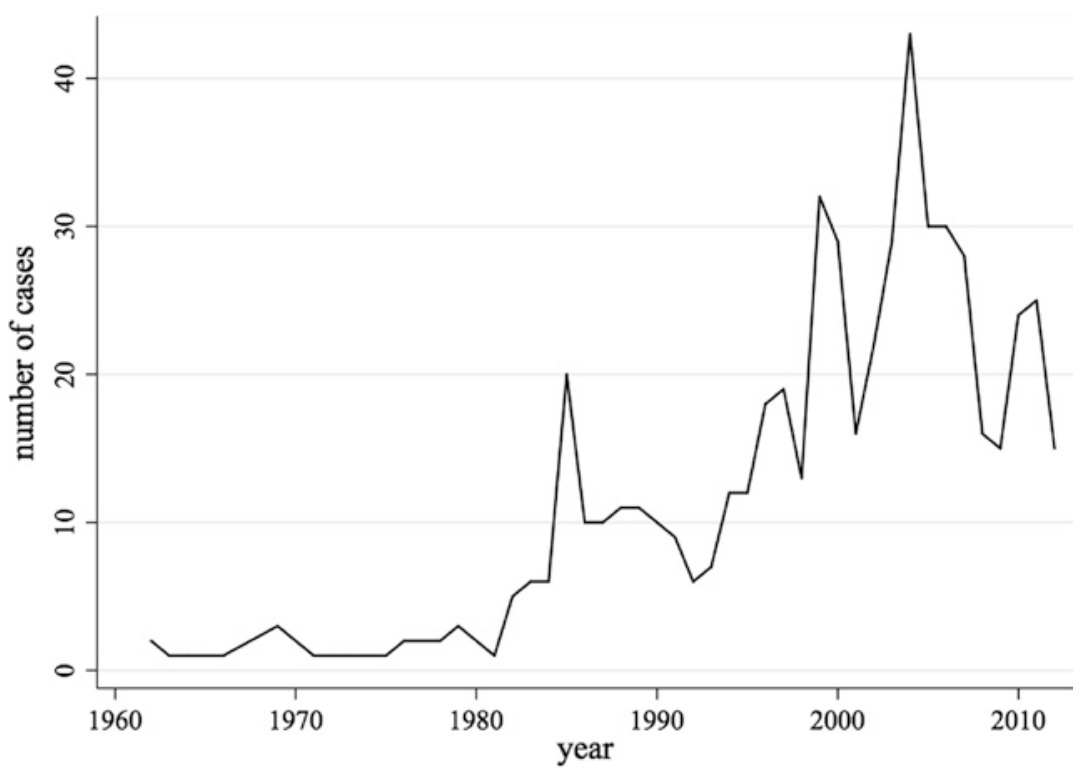

Fig. 1.1 Total number of actions for annulment by year of initiation (Source Own collection based on Stone Sweet and Brunell [2007] and updated from CURIA [cut off 31 December 2012]) 


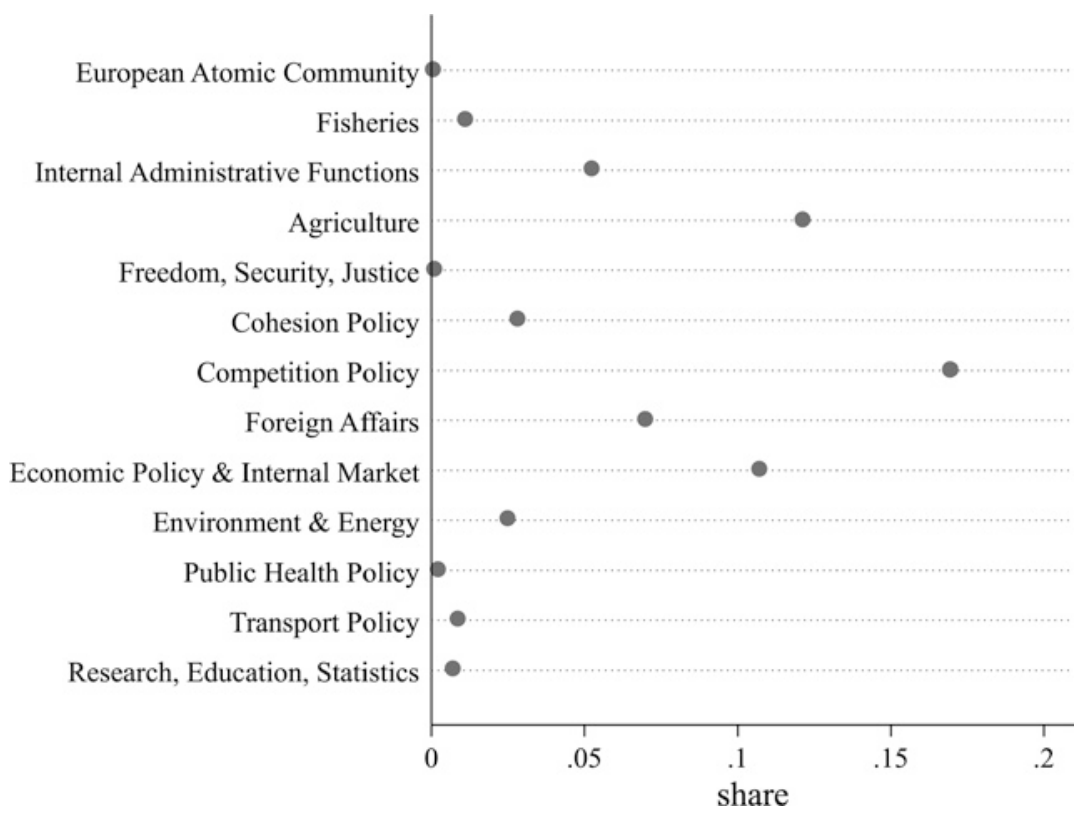

Fig. 1.2 Share of actions for annulment by policy sector (Source Own collection based on Stone Sweet and Brunell [2007] and updated from CURIA [cut off 31 December 2012])

active (see Fig. 1.2). While annulment actions occurred early in traditional areas of EU activity - such as agriculture or state aid and competition policy-expansion of supranational competences in foreign affairs (broadly defined with external affairs, trade policy, and foreign and security policy) have been accompanied by rising numbers for annulment actions in those areas, too.

Quite importantly, all major EU institutions have been confronted with annulment actions. While filing actions for annulment was initially meant to be a way for national governments to keep the High Authority - as predecessor of today's Commission - in check, actions for annulment are no longer raised only against the supranational executive. Around $20 \%$ of the annulment actions are directed against the Council, the EP, or the European Central Bank (ECB). The bulk of annulment cases - around $80 \%$ - however, still object to executive measures adopted by the Commission (see Fig. 1.3). 


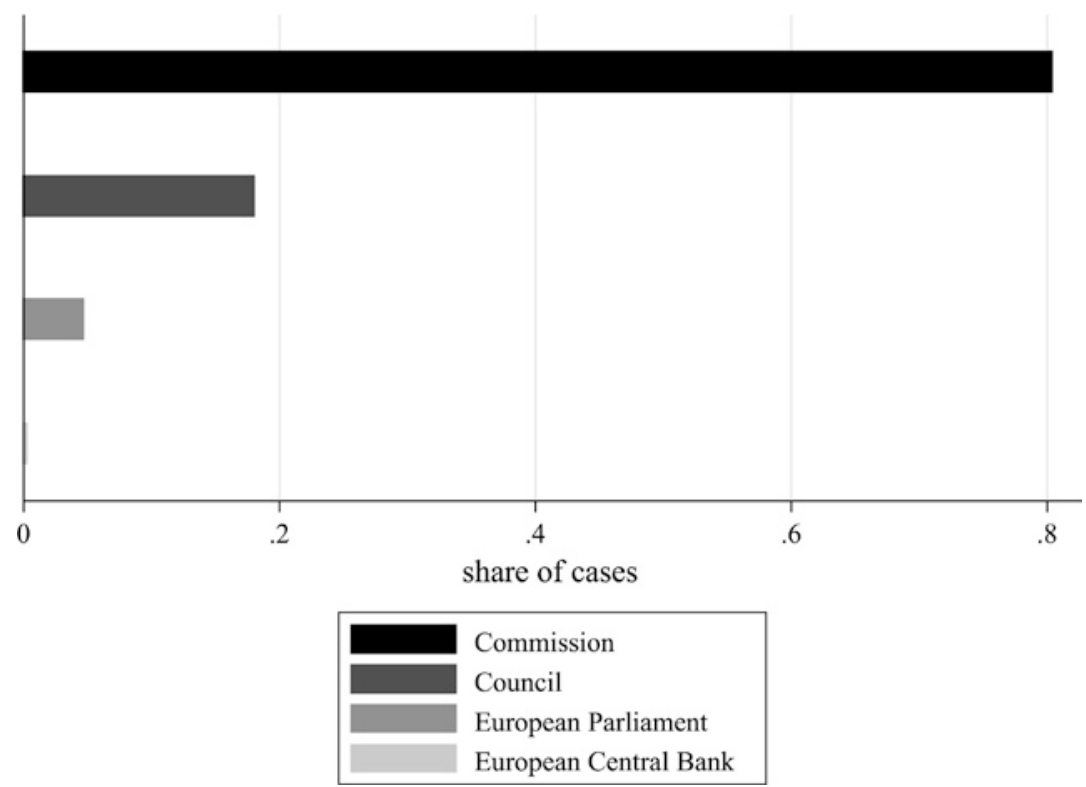

Fig. 1.3 Share of actions for annulment by defendant (Source Own collection based on Stone Sweet and Brunell [2007] and updated from CURIA [cut off 31 December 2012])

A look at the types of actors that initiate actions for annulment completes the rather complex picture we have drawn so far. While initially, annulment litigation was thought to be an instrument of judicial control for national governments against supranational institutions, today, a rather broad range of litigants launch annulment actions. Figure 1.4 indicates that private actors (individuals, companies, and interest groups), regional entities (regional or local authorities), national governments (i.e. member states), as well as EU institutions themselves actively use and initiate annulment actions in their struggles with (other) EU institutions. By 2012, private actors initiated the majority of annulments. Among public claimants, member states and EU institutions file a similar number of annulments. Subnational public actors are clearly less active. ${ }^{6}$

Concerning applicants, we observe interesting dynamics over time. The number of actions initiated by private applicants has boomed. 


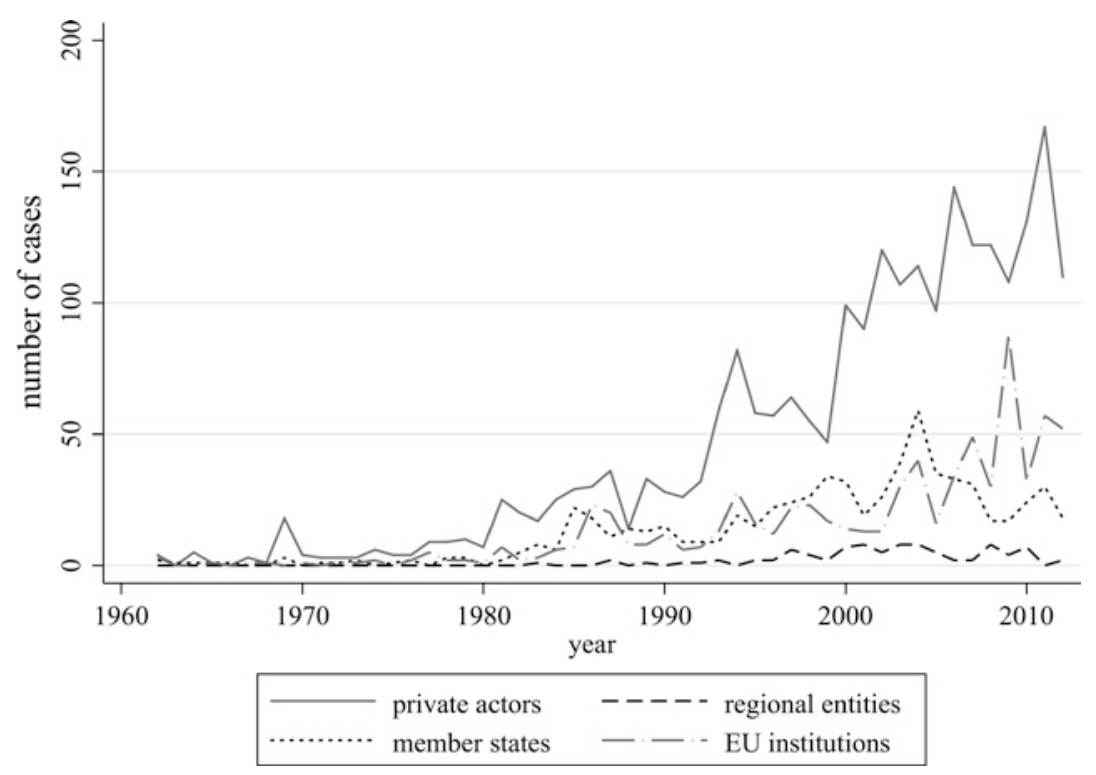

Fig. 1.4 Total actions for annulment by type of applicant (Source Own collection based on Stone Sweet and Brunell [2007] and updated from CURIA [cut off 31 December 2012])

Remarkably, EU institutions themselves increasingly sue each other, a tendency that has consolidated over time and even exceeded the number of actions initiated by the member states in the mid-2000s (Hartlapp 2018). At the same time, national governments have become somewhat more reluctant to litigate against EU institutions. As for regional actors, they have consistently been among the least active applicants. ${ }^{7}$ We thus see an interesting changing structure of conflict cleavages over time in annulment litigation (Adam 2018).

These changes over time and the increased diversity in the type of litigants are partly the result of the evolution of actors' standing rights. The conditions under which each type of actor (other than member states governments, the Commission, and the Council) can initiate annulment actions are detailed in the treaties. Their interpretation by the Court and the corresponding treaty-based provisions have, however, evolved over time, leading to an extended access to the CJEU in 
the form of judicial review for an ever greater variety of litigants (Arnull 1995, 2001; see also Chapter 3). To some extent, these developments regarding standing rights for different actors factor into the empirical patterns of annulment litigation that we observe. And yet, the development of these standing rights was driven by politically motivated annulment litigation in the first place. Actors that had not enjoyed the right to initiate annulments or had only limited rights to do so, such the EP, for example, bring litigation despite little to no chance of being admitted to the Court in the hope of provoking influential precedent rulings extending their standing rights; something the EP managed to accomplish with their annulment action in the so-called Chernobyl case (70/88 Parliament v. Council).

In sum, empirical patterns of annulment litigation suggests that actions for annulment have become an increasingly relevant judicial tool in the struggle over policy content and decision competences in the EU. Corresponding with the expansion of EU competences over time and across policy fields, the rising powers of EU institutions such as the EP and the ECB, the need for (and use of) judicial review has also grown in proportion. Initially restricted to actions against the Commission in a limited number of policy sectors such as agriculture and state aid, the use of annulment actions rose in frequency, covered an ever greater range of policy fields, and came to be directed against virtually all EU institutions. The list of applicants has grown more heterogeneous as well. Private actors, regional authorities, the EP, and EU institutions themselves file annulment actions ever more frequently.

\section{STRUCTURe OF THE BoOK}

The next chapter has two parts (Chapter 2). First, we review the literature on multilevel governance, public policy, and judicial politics in the EU and highlight what the analysis of annulment actions brings to each of these literatures. Secondly, this allows us to identify three questions (on motivations, actor constellations, and outcomes of the rulings and effects) that organize the litigation chain we present in our book. Next, we present the legal background of annulment actions (Chapter 3 ) to the extent that it structures opportunities and constraints for our policy actors when considering raising annulment 
actions. We proceed with a presentation of our data collection strategy and of the logic behind the empirical analysis that we employ (Chapter $4)$. We do so before presenting three chapters that present empirical evidence and develop theoretical arguments related to our four research questions. The first of these empirical chapters explores the different types of motivations underlying public actors' decisions to turn policy conflicts into annulment actions (Chapter 5). The second empirical chapter explores the factors behind the emergence of complex and multilevel actors' constellations in annulment proceedings (Chapter 6). The third empirical chapter covers our last two questions: the impact of actors' constellations on success in court and the impact of annulment actions on the multilevel policy conflicts they originate from (Chapter 7 ). The conclusion summarizes our findings and wraps up our main argument, while also suggesting avenues for further research in the area (Chapter 8 ).

We hope that this book makes a strong case for the need to understand annulment actions as a class of legal proceedings with political intent and impact in EU multilevel policy making. Yet even if we only manage to set out a new area waiting for empirical analyses in the field of law and politics-or just add to the intellectual controversy over the political importance of EU annulments, for that matter-we will be satisfied. Annulment litigation has become too important to continue being ignored by political analysis.

\section{Cases Cited}

See Table 1.1.

Table 1.1 Cases cited in this chapter

C-22/70 Judgment of 31 March 1971, Commission v. Council, C-22/70, EU:C:1971:32

C-344/01 Judgment of 4 March 2001, Germany v. Commission, C-344/01, EU:C:2004:121

T-21/06 Judgment of 6 October 2009, Germany v. Commission, T-21/06, EU:T:2009:387

T-892/16 Order of 15 December 2017, Apple v. Commission, T-892/16, EU:T:2017:925f 


\section{Notes}

1. Throughout this book, we refer to the Court of Justice of the European Union as 'the Court'. Thereby, we typically refer to both the Court of Justice and the General Court, depending on the competent court in the respective case, without specifying this court more specifically.

2. Order of 15 December 2017, Apple v Commission, T-892/16, EU:T:2017:925f.

3. TFEU stands for Treaty on the Functioning of the European Union. A list of abbreviations is provided at the beginning of the book.

4. The legal dispute did not end there. Despite the pending annulment decision, Ireland is obliged to recover the state aid deemed illegal. As Ireland's progress was too slow in the eyes of the Commission-several deadlines for calculating and collecting the illegal state aid were missed by the Irish government-the Commission decided to take Ireland to the Court of Justice for failure to implement the Commission decision, in accordance with Article 108(2) of the TFEU (see http://europa.eu/rapid/press-release_IP-17-3702_en.htm, accessed 4 October 2017). In response to this, Ireland collected the money from Apple in September 2018; funds are currently being held in escrow while the annulment case is still pending in court.

5. The acronym COM indicates that the interviewee works for the European Commission. The logic behind codifying the interview sources is explained in more detail in Chapter 4. All interviews conducted in the preparation of this research are listed in the Annex.

6. In some countries, subnational authorities have formal agreements with their national governments stating that in case a subnational government wants to file an annulment against EU institutions, the case is formally brought forward by the member state's central administration.

7. Regional governments and private actors face stricter legal requirements than governments or EU institutions for CJEU consideration of the cases that they raise (cf. Chapter 3).

\section{REFERENCES}

Adam, C. (2016). The politics of judicial review: Supranational administrative acts and judicialized compliance conflict in the EU. Basingstoke, UK: Palgrave Macmillan.

Adam, C. (2018). Multilevel conflict over policy application-Detecting changing cleavage patterns. Journal of European Integration, 40(6), 683-700.

Adam, C., Bauer, M. W., \& Hartlapp, M. (2015). It's not always about winning: Domestic politics and legal success in EU annulment litigation. Journal of Common Market Studies, 53(2), 185-200. 
Arnull, A. (1995). Private applicants and the action for annulment under Article 173 of the EC treaty. Common Market Law Review, 32, 7-49.

Arnull, A. (2001). Private applicants and the action for annulment since CODORNIU. Common Market Law Review, 38, 7-52.

Bauer, M. W., \& Hartlapp, M. (2010). Much ado about money and how to spend it! Analysing 40 years of annulment cases against the European Union Commission. European Journal of Political Research, 49, 202-222.

Burley, A.-M., \& Mattli, W. (1993). Europe before the court: A political theory of legal integration. International Organization, 47(1), 41-76.

Cremona, M. (2011). External relations and external competences of the European Union: The emergence of an integrated policy. In P. Craig \& G. de Burca (Eds.), The Evolution of EU Law (pp. 217-268). Oxford, UK: Oxford University Press.

European Commission. (2005, June 7). State aid action plan-Less and better targeted state aid: A roadmap for state aid reform 2005-2009. COM (2005) 107 final. http://eur-lex.europa.eu/LexUriServ/LexUriServ.do? uri=CELEX:52005DC0107:EN:NOT. Accessed 9 April 2013.

Federal Republic of Germany. (2005). Stellungnabme der Bundesregierung der Bundesrepublik Deutschland zum 'Aktionsplan staatliche Beibilfen' vom 5.10.2005. http://ec.europa.eu/competition/state_aid/reform/comments_ saap/37982.pdf. Accessed 7 December 2017.

Hartlapp, M. (2018). Power shifts via the judicial arena: How annulments cases between EU institutions shape competence allocation. Journal of Common Market Studies, 56(6), 1429-1445.

Houlder, V., Barker, A., \& Beesley, A. (2016, August 30). Apple's EU tax dispute explained: The consequences of the commissions complaint and the wider implications of its ruling. Financial Times. https://www.ft.com/ content/3e0172a0-6elb-11e6-9acl-1055824ca907.

Laufer, H., \& Münch, U. (1998). Das föderative System der Bundesrepublik Deutschland. Stuttgart, Germany: UTB.

Mathieu, E., Adam, C., \& Hartlapp, M. (2018). From high judges to policy stakeholders: A public policy approach to the CJEUs power. Journal of European Integration, 40(6), 653-666.

Meyer, D., \& Boutcher, S. (2007). Signals and spillover: Brown vs. Board of Education and other social movements. Perspectives on Politics, 1, 81-93.

Stone Sweet, A., \& Brunell, T. L. (2007). Data set on actions under Article 230: 1954-2006. NEWGOV Project. San Domenico di Fiesole, Italy: Robert Schuman Centre, European University Institute.

Swenden, W. (2006). Federalism and regionalism in Western Europe: A comparative and thematic analysis. Basingstoke, UK: Palgrave.

Tallberg, J. (2002). Paths to compliance: Enforcement, management, and the European Union. International Organization, 56, 609-643. 
Open Access This chapter is licensed under the terms of the Creative Commons Attribution 4.0 International License (http://creativecommons.org/licenses/ by $/ 4.0 /)$, which permits use, sharing, adaptation, distribution and reproduction in any medium or format, as long as you give appropriate credit to the original author(s) and the source, provide a link to the Creative Commons license and indicate if changes were made.

The images or other third party material in this chapter are included in the chapter's Creative Commons license, unless indicated otherwise in a credit line to the material. If material is not included in the chapter's Creative Commons license and your intended use is not permitted by statutory regulation or exceeds the permitted use, you will need to obtain permission directly from the copyright holder.

(c) (1) 